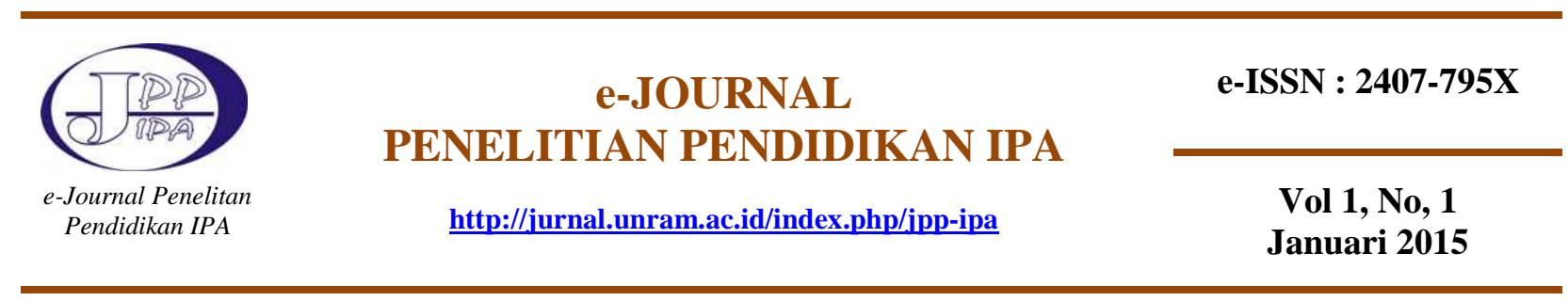

\title{
PENGARUH MEDIA PEMBELAJARAN BERBASIS MOODLE TERHADAP PENINGKATAN KEMAMPUAN GENERIK SAINS SISWA SMK
}

\author{
Desak Made Anggraeni ${ }^{1}$, Susilawati ${ }^{2}$, Gunawan ${ }^{3}$ \\ Program Studi Magister Pendidikan IPA Program Pascasarjana Universitas Mataram ${ }^{123}$ \\ Desak.madeanggraeni@yahoo.com, susilawatihambali@yahoo.co.id, fisgun_unram@yahoo.co.id
}

\begin{tabular}{ll}
\hline Key Words & Abstract \\
\cline { 1 - 1 } $\begin{array}{l}\text { Moodle-Based } \\
\text { Mearning }\end{array}$ & The purpose of this study was to determine the influence of media-based learning \\
Skills & moodle to increase students' generic skills in materials science impulse and \\
& momentum. The method used is the method of quasi-experimental research \\
design with untreated control group design with pretest and posttest. A total of 53 \\
students were divided into experimental group and control group were included in \\
this study. Research instruments using generic science skills test in the form of \\
descriptions about. Data analysis using the test "mean-difference" and \\
"normalized gain scores". Based on the results of this study concluded that the use \\
of media-based learning moodle does not result in a significant increase in the \\
ability of generic science class experiment between students and classroom \\
control. But based on the achievement of values, the average value of the ability \\
of generic science experiments grade higher than the control class.
\end{tabular}

\begin{tabular}{|c|c|}
\hline Kata Kunci & Abstrak \\
\hline $\begin{array}{l}\text { Media } \\
\text { Pembelajaran } \\
\text { Berbasis } \\
\text { Moodle, } \\
\text { Kemampuan } \\
\text { Generik Sains }\end{array}$ & $\begin{array}{l}\text { Tujuan penelitian ini adalah untuk mengetahui pengaruh media pembelajaran } \\
\text { berbasis moodle terhadap peningkatan kemampuan generik sains siswa pada } \\
\text { materi impuls dan momentum. Metode penelitian yang digunakan adalah metode } \\
\text { kuasi eksperimen dengan desain penelitian untreated control group design with } \\
\text { pretest and posttest. Sebanyak } 53 \text { orang siswa yang terbagi dalam kelompok } \\
\text { eksperimen dan kelompok kontrol dilibatkan dalam penelitian ini. Instrumen } \\
\text { penelitian menggunakan uji kemampuan generik sains dalam bentuk soal uraian. } \\
\text { Data analisis menggunakan uji "mean-difference" dan "normalized gain } \\
\text { scores". Berdasarkan hasil penelitian dapat disimpulkan bahwa penggunaan } \\
\text { media pembelajaran berbasis moodle tidak menghasilkan peningkatan yang } \\
\text { signifikan untuk kemampuan generik sains antara siswa kelas eksperimen dan } \\
\text { kelas kontrol. Tetapi berdasarkan pencapaian nilai, rata-rata nilai kemampuan } \\
\text { generik sains siswa kelas ekperimen lebih tinggi dibandingkan kelas kontrol. }\end{array}$ \\
\hline
\end{tabular}




\section{PENDAHULUAN}

Media belajar merupakan salah satu alat bantu dalam kegiatan pembelajaran. Paradigma baru dalam pembelajaran mulai bergeser dari pembelajaran tatap muka (face to face course) secara langsung antara guru dan siswa ke pembelajaran modern berbasis internet(E-learning).E-learning adalah istilah popular yang digunakan untuk menggambarkan penggunaan teknologi dalam pendidikan. Pengembangan E-learning di Indonesia saat ini tampak semakin banyak dilakukan baik oleh institusi pendidikan untuk kepentingan interent proses pembelajaran, dan melengkapi sistem pembelajaran konvensional yang ada. Dukungan dari pemerintah, terutama dari Direktorat Jenderal Pendidikan Tinggi Kementerian Pendidikan \& Kebudayaan merangsangbeberapa universitas dan lembaga pendidikan di Indonesia untuk melakukan inovasi pada sistem pembelajaran. Hal ini sejalan dengan landasan yuridis implementasi teknologi dalam bidang pendidikan (E-learning) adalah UU Nomor 14/2005 tentang Guru dan Dosen menyatakan bahwa "setiap guru harus dapat memanfaatkan teknologi informasi dan komunikasi untuk kepentingan penyelenggaraan pengembangan yang mendidik".

Teknologi dalam E-learningdigunakan sebagai media untuk meningkatkan kualitas pembelajaran interaktif dan dukungan pada pelaksanaan pertemuan tatap muka di kelas. MelaluiE-learning materi pembelajaran dapat diakses kapan saja dan dimana saja,disamping itu materi dapat diperkaya dengan berbagai sumber belajar termasuk multimedia dengan cepat dapat diperbaharui oleh pengajar.Selain itu, fasilitas yang ditawarkan dalam pembelajaranE-learning adalah dapat menampilan materi-materi pembelajaran yang bersifat abstrak menjadi materi yang dapat disaksikan secara langsung.Salah satu contoh materi yang banyak bersifat abstrak adalah materi pada pelajaran fisika.

Mata pelajaran fisika mempersiapkan siswauntuk mengembangkan program keahlian mereka pada tingkat pendidikan yang lebih tinggi.Penguasaan mata pelajaran fisika memudahkan siswa menganalisis proses-proses yang berkaitan dengan perkembangan teknologi informasi dari waktu ke waktu.Pembelajaran fisika di SMK belum banyak menyentuh kemampuan dan adaptasi siswa. Hal tersebut disebabkan dalam proses pembelajaran siswa kurang dilatih kemampuandasar yang sangat berkaitan dengan dunia kerja atau masa depan. Salah satu kemampuan dasar yang harus dimiliki siswa adalah kemampuan generik sains. 
Kemampuan generik sains merupakan kemampuan yang diperlukan untuk berbagai bidang pekerjaan dan kehidupan (Widodo, 2009).Secara umum terdapat sembilan kemampuan generik yang dapat dikembangkan melalui pengajaran fisika, yang meliputi: (1) pengamatan langsung, (2) pengamatan tidak langsung, (3) kesadaran tentang skala besaran, (4) bahasa simbolik,(5) kerangka logika taat azas dari hukum alam, (6) inferensi atau konsistensi logika, (7) hukum sebab akibat,(8) pemodelan matematis, dan(9) membangun konsep (Brotosiswoyo,2000). Dalam proses pembelajaran, kemampuan generik sains harus dilatihkan kepada siswa agar mereka dapat memiliki kemampuan dasar yang sangat berguna untuk melanjutkan pendidikan dan kesuksesan karier.

Penelitian mengenai kemampuan generik sains dan penguasaan konsep telah banyak dilakukan. Beberapa hasil dari penelitian menyimpulkan bahwa penggunaan berbagai media pembelajaran dapat dijadikan sebagai salah satu cara untuk melatih dan mengembangkan kemampuan generik sains siswa sehingga penguasaan konsep dari materi pembelajaran dapat lebih maksimal. Seperti dalam Wiyono (2012) menjelaskan bahwa pengembangan model multimedia interaktif adaptif pendahuluan fisika zat padat (MIA-PIZA) dapat meningkatkan penguasaan konsep dan keterampilan berpikir kritis mahasiswa calon guru.Gunawan (2010) menyimpulkan bahwa adanya peningkatan penguasaan konsep, keterampilan generik sains, dan disposisi berpikir kritis mahasiswa calon guru yang belajar dengan virtual laboratory. Selain itu, Marzani (2011) menyatakan bahwa adanya peningkatan penguasaan konsep dan kemampuan generik sains siswa yang mengikuti pembelajaran fisika pada konsep cahaya menggunakanElearning berbasis moodle.

E-learning adalah sistem pendidikan yang menggunakan aplikasi elektronik untuk mendukung belajar mengajar dengan media internet, jaringan komputer, maupun komputer standalone.Dalam proses penyelenggaraanE-learning dibutuhkan sebuah learning management system (LMS), yang berfungsi untuk mengatur tata laksana penyelenggaraan pembelajaran didalam model E-learning (Priowirjanto,2010). Moodle merupakan perangkat lunak open source yang mendukung implementasiE-learning dengan paradigma terpadu dimana berbagai fitur penunjang pembelajaran dengan mudah dapat diakomodasikan dalam suatu portalE-learning. Keunggulan dari moodle adalah (1) sederhana, efisien, ringan dan kompatibel dengan banyak browser, (2) mudah cara instalasinya serta mendukung banyak bahasa termasuk Indonesia, (3) 
tersedianya manajemen situs untuk pengaturan situs keseluruhan, mengubah tema, menambah modul, dan sebagainya,(4) tersedianya manajemen penggunaan kursus, penambahan jenis kursus, pengurangan, atau pengubahan kursus, (5) modul chat, modul pemilihan (polling), modul forum, modul untuk jurnal, modul untuk kuis, modul untuk survey dan workshop, (6) free dan open source software(http:www.Moodle.org). Berkaitan dengan software LMS moodle tersebut, komponen E-learning dalam produk yang dikembangkan ini diorganisir dari keempat komponen dalam proses pembelajaran yang meliputi :materi ajar, metode pendekatan, media, penugasan dan evaluasi.

Kegiatan penyelenggaraan pembelajaran online tentu saja membutuhkan fasilitas fisik maupun sumber daya manusia yang mendukung. Observasi awal yang dilakukan peneliti pada SMK jurusan teknologi di kota Mataram diperoleh kesamaan data bahwa(1)sistem pembelajaran fisika masih bersifat konvensional, peran guru yang berlangsung selama ini masih sangat dominan dimana proses pembelajaran hanya ditekankan pada mencatat konsep-konsep fisika dan menghapal rumus-rumus, (2) tidak tersedianya media untuk pembelajaran pada mata pelajaran fisika baik media riil maupun media virtual, (3) sumber pembelajaran siswa hanya menggunakan LKS dari penerbit tertentu, bahkan ada sekolah yang siswanya tidak memiliki LKS dan buku pegangan untuk siswa,(4) dalam proses pembelajaran, mata pelajaran fisika hanya diberikan2 x jam pelajaran dalam 1 minggu untuk tatap muka,keterbatasan waktu pembelajaran tersebut bertolak belakang dengan jumlah materi yang harus dikuasai oleh siswa. Hal tersebut mengakibatkan siswa hanya menghafal materi pelajaran namun tidak menguasai konsep dari materi pelajaran yang diberikan.

Data-data yang diperoleh dari kegiatan observasi awal menunjukkan bahwa terdapat kesenjangan antara kondisi ideal dan kondisi riil di lapangan. Kondisi ideal menghendaki siswa aktif dalam proses pembelajaran, menguasai konsep-konsep fisika serta mengembangkan kemampuan dasar sains. Namun disisi lain kondisi riil menunjukkan pembelajaran yang sangat minim untuk mengembangkan kemampuankemampuan dasar sains dan tidak berorientasi pada pelibatan aktivitas siswa sehingga penguasaan siswa terhadap konsep-konsep fisika masih rendah. Guru fisika jarang berinovasi untuk mengembangkan media pembelajaran serta memanfaatkan fasilitas yang ada, ketersediaan sarana di sekolah yang tidak mendukung pembelajaran fisika yang ideal, ketidaksesuaian waktu tatap muka dengan jumlah materi yang harus dipelajari serta ditempatkannya fisika sebagai mata pelajaran pelengkap (tidak 
diikutsertakan dalam ujian nasional) menjadi faktor yang mendukung kondisi riil tersebut.

Berdasarkan latar belakang diatas maka penulis melakukan penelitian mengenai pengaruh penggunaan media pembelajaran berbasis moodleterhadap peningkatan kemampuan generik sains siswa SMK.

\section{METODE}

Penelitian ini termasuk jenis penelitian eksperimen. Untuk pengujian efektivitas media pembelajaran berbasis moodle terhadap peningkatan kemampuan generik sains dan penguasaan konsep digunakan metode kuasi eksperimen dengan desain untreated control group designwith pretest and posttest. Desain penelitian seperti ditampilkan pada Tabel 1 berikut.

Tabel 1 Desain Penelitian

\begin{tabular}{lccc}
\hline Kelompok & Tes Awal & Perlakuan & Tes Akhir \\
\hline Eksperimen & O1 & $\mathrm{X} 1$ & O2 \\
Kontrol & $\cdots \cdots \cdots \cdots \cdots \cdots \cdots \cdots \cdots \cdots \cdots \cdots \cdots$ & O3 4 \\
\hline
\end{tabular}

O1 dan O3 adalah tes awal, O2 dan O4 adalah tes akhir yang dilakukan untuk mengukur kemampuan generik sains siswa sebelum dan sesudah perlakuan. X1 adalah perlakuan untuk kelas eksperimen, yaitu pembelajaran menggunakan media berbasis moodle, sedangkan $\mathrm{X} 2$ adalah pembelajaran konvensional berbantuan media power point untuk kelas kontrol.

Untuk memperoleh data penelitian, digunakan instrumen tes kemampuan generik sains berbentuk soal uraian sebanyak 5 soal Subyek penelitian ini adalah siswa kelas X jurusan RPL yang mengikuti pelajaran fisika materi momentum dan impuls di sebuah SMK negeri di Mataram. Siswa dibagi menjadi 2 kelompok, yaitu kelompok eksperimen dan kelompok kontrol, masing-masing 27 orang dan 26 orang.

Untuk mengetahui peningkatan kemampuan generik sains siswa dilakukan dengan menghitung besarnya skor gain yang dinormalisasi ( $N$-gain). Hal ini dimaksudkan untuk menghindari kesalahan dalam menginterpretasikan perolehan gain masingmasing siswa. Untuk memperoleh skor $N$-gain digunakan rumus (Bao, 2006).

$$
\mathrm{N}-\text { gain }=\frac{S_{\text {post }}-S_{\text {pre }}}{S_{\text {maks }}-S_{\text {pre }}} \times 100 \%
$$

Keterangan : 
$\mathrm{N}-$ gain $\geq 70 \%$ (tinggi); $30 \%<N-$ gain $\leq 70 \%$ (sedang); $\mathrm{N}-$ gain $\leq 30 \%$ (rendah).

Pengolahan data diawali dengan uji statistik berupa uji normalitas dan uji homogenitas. Selanjutnya, dilakukan uji perbedaan dua rerata untuk menguji tingkat signifikansi perbedaan rerata skor tes kemampuan generik sains (kelas eksperimen dan kelas kontrol).

\section{HASIL}

Perolehan skor rata-rata tes awal, tes akhir dan $\mathrm{N}$-gain pada kelas eksperimen dan kelas kontrol dapat dilihat pada Tabel 2.Analisis data gain ternormalisasi dilakukan untuk melihat adanya perbedaan peningkatan kemampuan generik sains siswa antara kelas eksperimen dan kelas kontrol. Berdasarkan data pada Tabel2 menunjukkan bahwa peningkatan kemampuan generik sains kelas eksperimen lebih tinggi daripada peningkatan kemampuan generik sains kelas kontrol, yaitu masing-masing sebesar 19,23\% dan 15,22\% dengan selisih gain kelas eksperimen dan kelas kontrol sebesar $0,55 \%$, yang artinya perlakuan pada kelas eksperimen lebih baik dibandingkan dengan perlakuan yang diberikan pada kelas kontrol dalam meningkatkan kemampuan generik sains. Persentase skor kemampuan generik sains siswa pada kelas eksperimen dan kelas kontrol ditampilkan pada Gambar 1.

a. Uji Normalitas Distribusi Data

Uji normalitas distribusi data skor awal, tes akhir dan gain yang dinormalisasi kemampuan generik sains siswa kelas eksperimen dan kelas kontrol dapat dilihat pada Tabel 3. Dari Tabel 3 terlihat bahwa hasil uji normalitas distribusi data skor tes awal, tes akhir dan gain ternormalisasi kelas eksperimen dan kelas kontrol menunjukkan besarnya nilai $\chi_{\text {hitung }}^{2}$ lebih kecil daripada $\chi_{\text {tabel }}^{2}$ pada masing-masing nilai $d k$ yang berbeda dan nilai $\alpha=0,05$. Dengan demikian dapat disimpulkan bahwa skor tes awal, tes akhir dan gain yang dinormalisasi kelas eksperimen dan kelas kontrol berdistribusi normal.

Tabel 2Deskripsi Skor Kemampuan Generik Sains Siswa Secara Umum

\begin{tabular}{|c|c|c|c|c|c|c|c|}
\hline & \multicolumn{3}{|c|}{ Kelas Eksperimen } & \multicolumn{3}{|c|}{ Kelas Kontrol } & \multirow[b]{2}{*}{$\begin{array}{l}\Delta \% \\
\langle\mathrm{~g}\rangle\end{array}$} \\
\hline & $\begin{array}{c}\text { Tes } \\
\text { Awal }\end{array}$ & $\begin{array}{c}\text { Tes } \\
\text { Akhir }\end{array}$ & $\begin{array}{c}\% \\
\langle\mathrm{~g}\rangle \\
\end{array}$ & $\begin{array}{c}\text { Tes } \\
\text { Awal }\end{array}$ & $\begin{array}{c}\text { Tes } \\
\text { Akhir }\end{array}$ & $\begin{array}{c}\% \\
\langle\mathrm{~g}\rangle \\
\end{array}$ & \\
\hline $\mathrm{N}\left(\sum\right.$ mahasiswa $)$ & 27 & 27 & & 26 & 26 & & \\
\hline Rata-rata & 26,63 & 40,74 & 19,23 & 15,77 & 26,19 & 15,22 & 0,55 \\
\hline
\end{tabular}

Ket : 〈g>adalah $N$-gain 


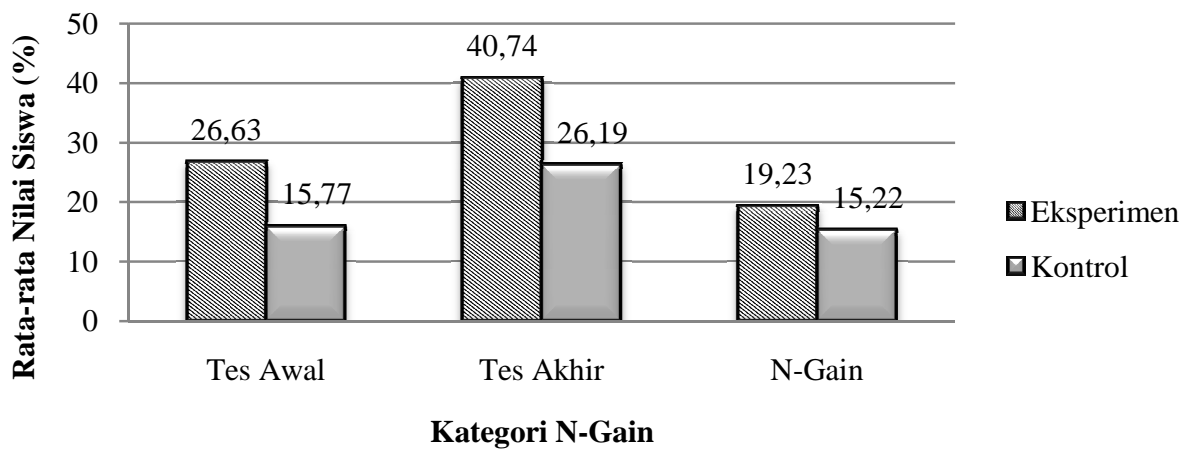

Gambar 1 Grafik Perbandingan Persentase N-Gain Kemampuan Generik Sains

Tabel 3 Hasil Uji Normalitas Data Skor Kemampuan Generik Sains Kedua Kelas

\begin{tabular}{cccccc}
\hline Sumber Data & Kelas & $\chi^{2}{ }_{\text {hitung }}$ & $d k$ & $\chi_{\text {tabel }}^{2}$ & Keputusan \\
\hline Tes Awal & Eksperimen & 11,000 & 17 & 27,587 & Normal \\
\cline { 2 - 6 } & Kontrol & 4,692 & 20 & 31,410 & Normal \\
\hline Tes Akhir & Eksperimen & 4,852 & 19 & 30,144 & Normal \\
\cline { 2 - 6 } & Kontrol & 1,692 & 23 & 35,172 & Normal \\
\hline Gain yang & Eksperimen & 2,815 & 22 & 33,924 & Normal \\
\cline { 2 - 6 } dinormalisasi & Kontrol & 3,077 & 20 & 31,410 & Normal \\
\hline
\end{tabular}

Tabel 4 Hasil Uji Homogenitas Skor Kemampuan Generik Sains Kedua Kelas

\begin{tabular}{cccc}
\hline Sumber Data & $F_{\text {hitung }}$ & $F_{\text {tabel }}$ & Keputusan \\
\hline Tes Awal & 1,577 & 1,937 & Homogen \\
\hline Tes Akhir & 1,031 & 1,937 & Homogen \\
\hline Gain yang dinormalisasi & 1,174 & 1,937 & Homogen \\
\hline
\end{tabular}

b. Uji Homogenitas Varians Data

Uji homogenitas varians data tes awal, tes akhir, dan gain yang dinormalisasi kedua kelas selengkapnya disajikan pada tabel 4 . Berdasarkan tabel 4 terlihat bahwa hasil uji homogenitas skor tes awal, tes akhir dan gain ternormalisasi memperlihatkan hasil yang sama. Untuk tes awal, tes akhir dan nilai gain ternormalisasi diperoleh nilai $F_{\text {hitung }}$ lebih kecil daripada nilai $F_{\text {tabel }}$ pada $\alpha=0,05$. Dengan demikian dapat disimpulkan varians data pada tes awal, tes akhir dan nilai gain ternormalisasi homogen.

c. Uji Beda Dua Rerata (Uji-t)

Kemampuan generik sains antara tes awal dan tes akhir memenuhi syarat terdistribusi normal dan mempunyai varians homogen. Oleh karena itu, dilakukan uji perbandingan $\mathrm{N}$-gain untuk variabel yang berpasangan dengan uji parametrik yaitu 
uji dua rerata (uji-t). Dari uji beda dua rerata (uji-t) diperoleh $t_{\text {hitung }}=1,496$ (pada df $=51, \alpha=0,05)$ dan $t_{\text {tabel }}=2,007$. Dari nilai yang diperoleh diketahui bahwa nilai $t_{\text {hitung }}$ lebih kecil daipada nilai $t_{\text {tabel }}$ maka Ho diterima dan Ha ditolak.Nilai tersebut diartikan bahwa tidak terdapat perbedaan yang signifikan antara nilai $\mathrm{N}$-gain kemampuan generik sains kelas eksperimen dan nilai $\mathrm{N}$-gain kemampuan generik sains kelas kontrol. Tetapi berdasarkan pencapaian rata-rata nilai $\mathrm{N}$-gain, diperoleh bahwa rata-rata nilai $\mathrm{N}$-gain kelas eksperimen lebih tinggi dibandingkan dengan kelas kontrol. Sehingga dapat disimpulkan ada peningkatan kemampuan generik sains siswa SMK yang mengikuti pembelajaran menggunakan media pembelajaran berbasis moodlelebih tinggi dibandingkan dengan siswa yang mengikuti pembelajaran konvensional.

Tabel 5Rekapitulasi Skor Kemampuan Generik Sains Setiap Indikator

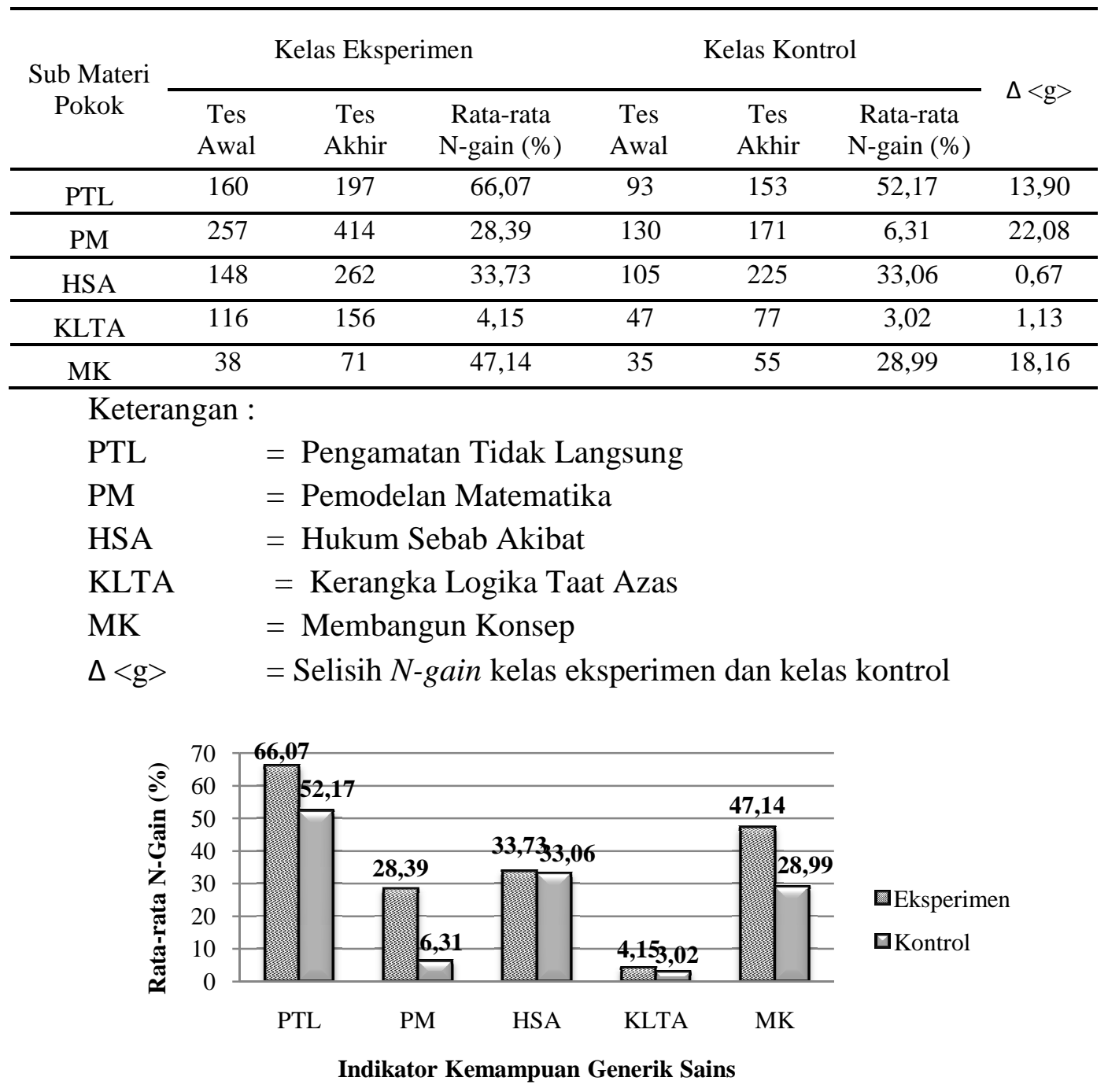

Gambar 2 Grafik N-Gain Kemampuan Generik Sains pada Setiap Sub Pokok Bahasan 
d. Kemampuan Generik Sains Siswa Setiap Indikator

Setiap indikator kemampuan generik sains dianalisis ketercapaiannya berdasarkan perolehan skor tes awal, skor tes akhir, dan $N$-gain. Peningkatan tertinggi kelas kontrol terjadi pada indikator pengamatan tidak langsung sebesar 52,17\% dengan kategori sedang dan peningkatan terendah terjadi pada indikator kerangka logika taat azas sebesar 3,02\% dengan kategori rendah, sedangkan peningkatan tertinggi kelas eksperimen terjadi pada indikator pengamatan tidak langsung sebesar 66,07\% pada kategori sedang dan peningkatan terendah terjadi pada indikator kerangka logika taat azas sebesar 4,15\% pada kategori rendah. Rekapitulasi skor kemampuan generik sains mahasiswa untuk setiap indikator ditampilkan pada Tabel 5. Berdasarkan Tabel 5 dapat diketahui bahwa perbedaan peningkatan tertinggi pada kedua kelas terjadi pada indikator pemodelan matematika sebesar 22,08\% sedangkan perbedaan terendah pada indikator hubungan sebab akibat sebesar 0,67\%.Berdasarkan persentase peningkatan kemampuan generik sains dapat diketahui bahwa terjadi peningkatan pada kedua kelas. Meskipun demikian persentase peningkatan kemampuan generik sains mahasiswa kelas eksperimen lebih tinggi dibandingkan mahasiswa kelas kontrol, artinya bahwa pembelajaran konsep impuls dan momentum dengan media pembelajaran berbasis moodle dapat meningkatkan kemampuan generik sains siswa lebih baik dari pembelajaran konvensional. Persentase skor kemampuan generik sains siswa pada kelas eksperimen dan kelas kontrol ditampilkan pada gambar 2.

\section{PEMBAHASAN}

Kemampuan generik sains merupakan kemampuan dasar ilmiah yang dapat ditumbuhkan melalui pembelajaran fisika yang bermanfaat sebagai bekal meniti karir dalam bidang yang lebih luas. Kemampuan generik sains dalam penelitian ini merujuk kepada teori yang dikemukakan oleh Brotosiswoyo (2000), disebutkan ada sembilan indikator kemampuan generik sains yang dapat dikembangkan melalui pengajaran fisika. Dari sembilan indikator kemampuan generik sains yang ada, dalam penelitian ini hanya difokuskan kepada 5 indikator kemampuan generik sains, yaitu: pengamatan tidak langsung, pemodelan matematika, kerangka logika taat azas, hukum sebab akibat, dan membangun konsep. Pemilihan indikator didasarkan pada pertimbangan karakteristik materi yang digunakan dalam penelitian ini yaitu materi mengenai impuls dan momentum. Seperti yang dijelaskan Marzuki (2010) bahwa indikator kemampuan generik sains yang digunakan dalam proses pembelajaran disesuaikan dengan materi 
serta proses pembelajaran yang akan dilakukan. Selain itu, Sunyono (2010) menjelaskan bahwa indikator kemampuan generik sains yang dikembangkan didasarkan pada karakteristik konsep dari materi yang akan digunakan.

Pengujian kemampuan generik sains siswa dilakukan dengan melihat dari hasil kognitif yang diperoleh oleh siswa yang berupa soal uraian.Pribadi (2009) menjelaskan bahwa tujuan ranah kognitif adalah untuk melatih kemampuan intelektual siswa agar mereka mampu menyelesaikan tugas-tugas yang bersifat intelektual yaitu kemampuan generik dan kemampuan berpikir tingkat yang lain. Terdapat lima soal uraian yang digunakan untuk mengukur lima indikator kemampuan generik sains yang dikembangkan. Soal yang diberikan pada tes awal sama dengan soal yang diberikan pada tes akhir. Tes awal dilakukan sebelum pembelajaran dilakukan untuk melihat kemampuan awal yang dimiliki oleh siswa, setelah itu diberikan perlakuan dengan pembelajaran menggunakan media pembelajaran berbasis moodle.Kemudian dilakukan tes akhir untuk mengetahui peningkatan kemampuan generik sains siswa.

Berdasarkan hasil analisis data diketahui bahwa tidak terdapat perbedaan yang signifikan untuk kemampuan generik sains siswa kelas eksperimen dan kelas kontrol, tetapi kedua kelas mengalami peningkatan kemampuan generik sains. Hal ini ditunjukkan dengan rata-rata persentase gain ternormalisasi kelas eksperimen sebesar 19,23\% (kategori rendah) lebih tinggi daripada kelas kontrol sebesar 15,22\% (kategori rendah). Sehingga terlihat bahwa tidak ada perbedaan yang signifikan dari peningkatan kemampuan generik sains kedua kelas. Namun jika dilihat dari nilai persentase gain ternormalisasi menunjukkan bahwa persentase peningkatan kelas eksperimen lebih tinggi dibanding dengan kelas kontrol. Hal ini sejalan dengan hasil penelitian Pratama (2011) bahwa media E-learning berbasis moodle efektif meningkatkan kemampuan generik sains. Selain itu, Marzani (2011) menjelaskan bahwa pengembangan pembelajaranE-learning moodle berpengaruh terhadap hasil belajar siswa sekolah menengah atas.

Peningkatan kemampuan generik sains pada kelas eksperimen disebabkan beberapa faktor.Pertama, tersedianya visualisasi video, animasi serta simulasi interaktif sehingga indikator kemampuan generik sains yang dikembangkan dapat dilatihkan kepada siswa.Kedua, faktor ketersediaan bahan ajar dan sumber untuk belajar tanpa batasan waktu.Hal tersebut karena siswa di kelas eksperimen dapat mengakses materi pembelajaran secara online dimana saja dan kapan saja. 
Peningkatan kemampuan generik sains juga tampak pada setiap sub materi. Berdasarkan hasil analisis data diperoleh bahwa peningkatan kemampuan generik sains setiap sub materi pada kelas eksperimen lebih tinggi daripada kelas kontrol. Hal tersebut dapat diartikan bahwa pembelajaran fisika menggunakan media pembelajaran berbasis moodle dapat meningkatkan kemampuan generik sains siswa.Adapun perbedaan peningkatan terbesar pada kedua kelas terjadi pada indikator pengamatan tidak langsung. Hal tersebut karena dalam media tersebut terdapat banyak video, gambar, tabel yang membantu siswa mengamati obyek serta materi pembelajaran secara tidak langsung karena obyek tersebut tidak dapat ditampilkan secara langsung saat proses pembelajaran.Sedangkan peningkatan kemampuan generik sains terendah terdapat pada indikator kerangka logika taat azas. Hal tersebut karena pada proses pembelajaran sebelumnya, siswa kurang memahami konsep-konsep yang diberikan. Proses pembelajaran hanya sebagai proses mendengarkan penjelasan guru dan mencatat materi, sehingga siswa hanya menghafal konsep yang diberikan.

Indikator kerangka logika taat azas memerlukan kemampuan siswa dalam memahami berbagai konsep fisika yang ada, sehingga ketika diberikan suatu konsep baru, mereka dapat memahami konsep tersebut melalui kerangka logis yang tidak melanggar azas atau hukum-hukum fisika yang berlaku.Brotosiswoyo (2000) menjelaskan bahwa aturan yang ada dialam memiliki sifat taat azas secara logika.Oleh karena itu, sangat penting penanaman konsep fisika pada siswa. Selain itu, faktor lain yang menyebabkan rendahnya peningkatan indikator kerangka logika taat azas adalah karena siswa belum terbiasa untuk belajar secara mandiri serta menyelesaikan permasalahan secara mandiri. Munir (2009) menjelaskan bahwa belajar mandiri adalah belajar dengan bantuan minimal dari pihak lain, bantuan belajar berupa segala bentuk kegiatan pendukung untuk membantu kelancaran proses belajar mandiri pada siswa. Oleh karena itu, pembelajaran mandiri pada siswa berdampak pada pola pikir siswa dalam menyelesaikan masalah yang diberikan.

Sejalan dengan pendapat Mubarak (2010) bahwa pembelajaran berbasis web dapat menumbuhkan kemandirian siswa untuk mengkontruksi sendiri pengetahuan mereka yang terlihat dari adanya peningkatan keterampilan generik sains siswa.Hasil pengamatan peneliti selama melakukan penelitian menunjukkan bahwa pada tes awal siswa yang belum memperoleh materi cenderung untuk asal menjawab soal yang diberikan.Kemudian ketika pembelajaran pada materi tersebut berlangsung, peneliti memperhatikan kebanyakan siswa kelas kontrol menunjukkan rasa ingin tahu dan sikap 
kritis pada saat mengerjakan soal yang diberikan masih rendah sehingga kemungkinan pada tes akhir siswa yang belum mengerti cenderung asal menjawab soal yang diberikan tentang materi tersebut.Hal ini memberikan kemungkinan hasil belajar siswa pada kelas kontrol lebih rendah daripada siswa kelas eksperimen.Sedangkan pada kelas eksperimen, siswa diberikan materi yang dapat diakses secara online oleh siswa. Siswa dapat memanajemen materi pembelajaran serta proses pembelajaran. Pembelajaran dan percobaan dapat dilakukan oleh sistem dengan sistem manajemen pembelajaran moodle (Kumar, 2011).

\section{PENUTUP}

Berdasarkan analisis data penelitian, dapat disimpulkan bahwa tidak terdapat perbedaan yang signifikanuntuk kemampuan generik sains antara yang mengikuti pembelajaran menggunakan media pembelajaran fisika berbasis moodle pada materi impuls dan momentum dibandingkan dengan siswa yang mengikuti pembelajaran konvensional. Tetapi berdasarkan pencapaian nilai, rata-rata nilai kemampuan generik sains siswa kelas eksperimen lebih tinggi dibandingkan kelas kontrol. Peningkatan tertinggi kelas kontrol terjadi pada indikator pengamatan tidak langsung sebesar $52,17 \%$ dengan kategori sedang dan peningkatan terendah terjadi pada indikator kerangka logika taat azas sebesar 3,02\% dengan kategori rendah, sedangkan peningkatan tertinggi kelas eksperimen terjadi pada indikator pengamatan tidak langsung sebesar 66,07\% pada kategori sedang dan peningkatan terendah terjadi pada indikator kerangka logika taat azas sebesar $4,15 \%$ pada kategori rendah.

\section{DAFTAR PUSTAKA}

Ali, M. 2004," E-learning in Indonesia Education System”, $7^{\text {th }}$ Programming Cycle of APEID Activities, Kyoto,Japan.

Andrews, T., Daly, C. 2008.Using Moodle, an open source learning management system, to support a national learning and teaching collaboration.Paper presented at Proccedings of the 2008 AaeE Conference, Yeppoon.

Arifin, Y. \& Sidin, U.S. 2009. Faktor-Faktor Terpenting dalam Pembangunan ELearning System.Jurnal MEDTEK, 1 (1) : 1, UNM.

Arikunto, S. 2009. Dasar-Dasar Evaluasi Pendidikan (Edisi Revisi).Jakarta : PT Bumi Aksara.

Bao, L. 2006. Theoritical Comparison of Average Normalized Gain Calculations.American Journal of Physics 74 910), October 2006. 
Brotosiswoyo, B.S. 2000. Hakikat Pembelajaran MIPA di Perguruan Tinggi.Jakarta : Universitas Terbuka.

BSNP.2006. Panduan Penyusunan Kurikulum Tingkat Satuan Pendidikan Jenjang Pendidikan Dasar dan Menengah.Jakarta : BSNP.

Dikmenjur. 2004. Kurikulum Sekolah Menengah Kejuruan Edisi 2004. Jakarta : Dikmenjur, Depdiknas.

Gunawan. 2010. Pengembangan Model Virtual Laboratory Fisika Modern untuk Mengingkatkan Penguasaan konsep dan Disposisi Berpikir Kritis Calon Guru.Disertasi S3 Tidak Diterbitkan.Universitas Pendidikan Indonesia.

Kumar, G. 2011. Using Moodle - An Open Source Virtual Learning Environment in the Academic.International Journal of Enterprise Computing Systems,(Online), 1 (1) : 1-1, (www.ijecbs.com), diakses 23 Februari 2013.

Marzani.2011. Efektifitas Media e-learning Berbasis Moodle untuk Meningkatkan Penguasaan Konsep dan Penguasaan konsep Siswa.Tesis tidak diterbitkan.Bandung : Universitas Pendidikan Indonesia.

Marzuki. 2010. Program Pembelajaran Fisika untuk Meningkatkan Pemahaman Konsep dan Penguasaan konsep Siswa Sekolah Menengah Pertama sebagai Upaya Membangun Kualitas Sumber Daya Manusia.Disertasi tidak diterbitkan.Universitas Pendidikan Indonesia.

Mubarak. 2010. Pengaruh Model Pembelajaran Berbasis Web (PBW) untuk Meningkatkan Keterampilan Generik Sains dan Penguasaan Konsep Siswa pada Materi Fluida Dinamis.Tesis tidak diterbitkan. Universitas Pendidikan Indonesia.

Munir.2009. Pembelajaran Jarak jauh Berbasis Teknologi Informasi dan Komunikasi.Bandung : Alfabeth.

Pratama, H. 2011. Pengembangan Pembelajaran E-Learning Berbasis Moodle pada Materi Pedosfer Kelas X Sekolah Menengah Atas.Tesis tidak diterbitkan. Malang:Universitas Negeri Malang.

Pribadi, B.A. 2011. Model Desain Sistem Pembelajaran. Jakarta : Dian Rakyat.

Priowirjanto, M. (2010).Pembelajaran Jarak Jauh Berbasis Moodle. Bandung : Alfabeta.

Setyosari, P. 2012. Metode Penelitian Pendidikan dan Pengembangan Edisi Kedua.Jakarta : Kencana.

Slavin, R.E. 2011. Psikologi Pendidikan Teori dan Praktek.Jakarta : PT Indeks.

Sudjana. 2002. Metoda Statistik Edisi Keenam. Bandung : Tarsito. 
Sugiyono. 2010. Statististik untuk Penelitian. Bandung : Penerbit Alfabeta.

Sukmadinata, N.S. 2011. Metode Penelitian Pendidikan. Bandung : Remaja.

Sunyono. 2010. Pengembangan Model Lembar Kerja Siswa Berorientasi Keterampilan Generik Sains pada Materi Kesetimbangan Kimia Rosdakarya. Prosiding Seminar Nasional Kimia dan Pendidikan Kimia. Solo.

Widodo.2009. Pembekalan Kemampuan-Kemampuan Fisika Bagi Calon Guru.Disertasi Doktor tidak diterbitkan.Bandung : Universitas Pendidikan Indonesia.

Wiyono. 2012. Pengembangan Model Multimedia Interaktif Adaptif Pendahuluan Fisika Zat Padat (MIA-PIZA) untuk Meningkatkan Penguasaan Konsep dan Keterampilan Berpikir Kritis Mahasiswa Calon Guru. Tesis tidak diterbitkan.Malang : Program Pascasarjana Universitas Malang. 